\title{
LncRNA PLAC2 upregulates miR-663 to downregulate TGF- $\beta 1$ and suppress bladder cancer cell migration and invasion
}

\author{
Zhenxing Zhang, Ping Ao, Hui Han, Qi Zhang, Yang Chen, Jie Han, Qunlian Huang, Houbao Huang and \\ Dong Zhuo* (1)
}

\begin{abstract}
Background: The roles of IncRNA PLAC2 in bladder cancer (BC) were explored.

Methods: The expression of PLAC2 in two types of tissue of BC patients was detected by RT-qPCR and the expression data were compared by paired t test. The 56 patients were staged according to the AJCC criteria, and $12,15,15$ and 14 cases were classified into stage I-IV, respectively. The expression of TGF- $\beta 1$ and miR-663 in BC tissues were also detected by RT-qPCR experiments.

Results: Our data showed that the expression levels of PLAC2 were significantly lower in BC tissues than that in non-cancer tissues. The expression of PLAC2 was not affect by clinical stages and low expression levels of PLAC2 predicted lower survival rate. The expression of PLAC2 was positively correlated with miR-663 and inversely correlated with TGF- $\beta 1$ in BC tissues. In BC cells, downregulated TGF- $\beta 1$ and upregulated miR-663 were observed after the overexpression of PLAC2. Overexpression of PLAC2 also resulted in suppressed invasion and migration of BC cells. Overexpression of miR-663 resulted in downregulated TGF- $\beta 1$ but did not affect the expression of PLAC2. Overexpression of TGF- $\beta 1$ reduced the inhibitory effects of overexpression of PLAC2 and miR-663 on cell migration and invasion.
\end{abstract}

Conclusion: PLAC2 can upregulate miR-663 to downregulate TGF- $\beta 1$ and suppress BC cell migration and invasion.

Keywords: Bladder cancer, IncRNA PLAC2, miR-663, TGF- $\beta 1$, Migration, Invasion

\section{Background}

Incidence of bladder cancer (BC) is one of the most common types of urological malignancy [1]. BC affects about 400, 000 new cases annually and about $40 \%$ of these patients die of $\mathrm{BC}$ within 5 years after the initial diagnosis [2]. Treatment of bladder cancer, such as surgical resection, has been improved significantly during the past several decades. However, most patients are diagnosed at advanced stages, which are not appropriate for surgery [3, 4]. Systemic

\footnotetext{
* Correspondence: zwasxgme52259582@126.com

* Correspondence: zwasxgme52259582@126.com
Department of Urology, The first affiliated hospital of Wannan Medical College, No. 2, Zheshan West Road, Jinghu District, Wuhu City, Anhui Province 241001, P. R. China
}

therapies and targeted therapies have shown promising potentials in the treatment of $\mathrm{BC}$ [5], while effective targets are limited and novel targets are urgently needed.

Long (> $200 \mathrm{nt}$ ) non-coding RNAs (lncRNAs) participate in human cancer biology by regulating the expression of tumor suppressive and oncogenic pathways [6,7]. Almost all the classic cancer-related pathways, such as the TGF- $\beta$ signaling, have crosstalk with lncRNAs $[8,9]$. It is generally believed that regulation of lncRNA expression may contribute to cancer treatment, while the functions of most lncRNAs are barely known [10]. LncRNA PLAC2 was demonstrated to be a cell cycle inhibitor in glioma, indicating its role as a tumor suppressor [11]. MiR-663 in

(c) The Author(s). 2020 Open Access This article is licensed under a Creative Commons Attribution 4.0 International License, which permits use, sharing, adaptation, distribution and reproduction in any medium or format, as long as you give appropriate credit to the original author(s) and the source, provide a link to the Creative Commons licence, and indicate if changes were made. The images or other third party material in this article are included in the article's Creative Commons licence, unless indicated otherwise in a credit line to the material. If material is not included in the article's Creative Commons licence and your intended use is not permitted by statutory regulation or exceeds the permitted use, you will need to obtain permission directly from the copyright holder. To view a copy of this licence, visit http://creativecommons.org/licenses/by/4.0/ The Creative Commons Public Domain Dedication waiver (http://creativecommons.org/publicdomain/zero/1.0/) applies to the data made available in this article, unless otherwise stated in a credit line to the data. 
cancer biology can target TGF- $\beta 1$ to inhibit cancer development [12], while TGF- $\beta 1$ can interact with the STAT signaling [13], which is regulated by PLAC2 [11]. The present study was carried out to explore the role of PLAC2 in BC with a focus on its interactions with miR663 and TGF- $\beta 1$.

\section{Methods}

\section{Patient admission and follow-up}

The present study enrolled $56 \mathrm{BC}$ patients from $166 \mathrm{BC}$ patients admitted to the first affiliated hospital of Wannan Medical College between July 2010 and December 2013. Inclusion criteria were:1) newly diagnosed cases; 2) patients were willing to participate in the 5-year follow-up and completed follow-up. Exclusion criteria were: 1) recurrent $\mathrm{BC} ; 2$ ) other clinical disorders were observed; 3) any therapies were initiated within 3 months before admission; 4) previous or family history of malignancies; 4) patients lost or died of other causes during follow-up. The 56 patients were staged according to the AJCC criteria, and 12,15, 15 and 14 cases were classified into stage I-IV, respectively. Based on the criteria of urothelial carcinoma grading established by American College of Surgeons, the 56 patients included 26 cases with high grade and 30 cases with low grade. This study was approved by the Ethics committee of aforementioned hospital. All patients were informed of the details of experiments and possible publication of this study, and they all signed the informed consent.

\section{Tissues}

All patients were diagnosed by histopathological biopsy. During biopsy, $\mathrm{BC}$ and adjacent (within $3 \mathrm{~cm}$ around tumors) non-cancer tissues $(0.08-0.12 \mathrm{~g})$ were collected from 3 different positions of the tumor. All tissues were confirmed by histopathological examinations.

\section{Cells and transient transfections}

Human BC cell line HT-1197 (ATCC, USA) was used. Eagle's Minimum Essential Medium was mixed with $10 \%$ fetal bovine serum (FBS) and was used as the culture medium. Cells were cultivated at $37{ }^{\circ} \mathrm{C}$ with $5 \%$ $\mathrm{CO}_{2}$. PLAC2 and TGF- $\beta 1$ expression vectors were constructed using pcDNA3.1 vector (Sangon, Shanghai, China). Negative control miRNA and miR-663 mimic were purchased from Sigma-Aldrich (USA). Inhibitor negative control and miR-663 inhibitor were also purchased from Sigma-Aldrich (USA). HT-1197 cells were harvested at the confluence of $70-90 \%$. Next, $10 \mathrm{nM}$ of LAC 2 and TGF- $\beta 1$ expression vector, $10 \mathrm{nM}$ of empty pcDNA3.1 vector (negative control, NC), $30 \mathrm{nM}$ of negative control (NC) miRNA and miR-663 mimic, or $30 \mathrm{nM}$ of inhibitor negative control (NC) and miR-663 inhibitor were transfected into $10^{5}$ cells using lipofectamine 2000 transfection reagent (Sigma-Aldrich, USA). Cells without transfections were used as the control $(\mathrm{C})$. the following experiments were performed using cells collected at $24 \mathrm{~h}$ post-transfection.

\section{RT-qPCR}

HT-1197 cells as well as tissues (ground in liquid nitrogen before use) were mixed with VWR Life Science RiboZol $^{\text {Ti }}$ RNA Extraction Reagent (VWR, USA) to extract total RNAs. Following DNase I digestion to remove genomic DNA, AMV Reverse Transcriptase (Canvax Biotech, USA) was used to synthesize cDNA through reverse transcription. The $\mathrm{qPCR}$ mixtures were prepared using KAPA SYBR FAST qPCR Master Mix (Kapa Biosystems). The expression of PLAC2 and TGF- $\beta 1$ were determined with GAPDH as the endogenous control. HT-1197 cells as well as tissues were also used to extract miRNAs using mirVana miRNA Isolation Kit (Thermo Fisher Scientific). Following miRNA reverse transcriptions using $\mathrm{MystiCq}^{\circ}$ microRNA cDNA Synthesis Mix (Sigma-Aldrich, USA), all qPCR reaction mixtures were prepared using miScript SYBR Green PCR Kit (QIAGEN, Germany). The expression of miR-663 was analyzed with U6 as endogenous control. Three biological replicates were included in each experiment and data were processed using $2^{-\triangle \Delta C T}$ method. Primer sequences were: TGF$\beta 1$ : (forward) 5'-TACCATGCCAACTTCTGTCTGGGA$3^{\prime}$ and (reverse) 5'-ATGTTGGACAACTGCTCCACCT TG-3'; PLAC2 (forward) 5'-AATGTCTTGGCCTT GAATGA-3' and (reverse) 5'-CAAACTCAGGGATA CATGGA-3'; GAPDH (forward) 5'-GCACCGTCAA GGCTGAGAAC-3' and (reverse) 5'-TGGTGAAGAC GCCAGTGGA-3'; miR-663: (forward) 5'-AGGCGG GGCGCCGCGGGACCGC-3'. U6 primers and miR-663 reverse primers were included in the kit.

\section{Cell migration and invasion assay}

HT-1197 cells $\left(3 \times 10^{4}\right)$ were harvested at $24 \mathrm{~h}$ after transfections and mixed with $1 \mathrm{ml}$ serum-free Eagle's Minimum Essential Medium to prepare single cell suspensions. Cells were transferred to the upper Transwell chamber ( $0.1 \mathrm{ml}$ per well) and the lower chamber was filled with Eagle's Minimum Essential Medium (20\% FBS). The membrane was coated with Matrigel (356,234, Millipore, USA) before invasion assay to mimic invasion condition. In migrtaion assay, uncoated membranes were used. Cells were cultivated at $37^{\circ} \mathrm{C}$ with $5 \% \mathrm{CO}_{2}$ for $8 \mathrm{~h}$, and membranes were cleaned and stained with $1 \%$ crystal violet (Sigma-Aldrich, USA) at $22^{\circ} \mathrm{C}$ for $15 \mathrm{~min}$. Stained cells were observed under an optical microscope.

\section{Western blot}

HT-1197 cells $\left(3 \times 10^{5}\right)$ were harvested at $24 \mathrm{~h}$ after transfections and mixed with $1 \mathrm{ml}$ RIPA solution 
(Beyotime, Jiangsu, China) to extract total proteins. Proteins were denatured and subjected to $12 \%$ SDS-PAGE gel electrophoresis. Membranes were first incubated with $5 \%$ non-fat milk at $22{ }^{\circ} \mathrm{C}$ for $2 \mathrm{~h}$, followed by incubation with TGF- $\beta 1$ and GAPDH rabbit polyclonal primary antibodies at $4{ }^{\circ} \mathrm{C}$ overnight. Then membranes were incubated with IgG-HRP goat anti rabbit (1:1000, MBS435036, MyBioSource) secondary antibody at $22{ }^{\circ} \mathrm{C}$ for $2 \mathrm{~h}$. Signals were developed using ECL (Sigma-Aldrich, USA) and Image J v1.46 software was used to process data.

\section{Statistical analyses}

Means values presented in this study were calculated using the data from 3 biological replicates. Differences between two types of tissue were compared using paired $t$ test. ANOVA Tukey's test was used to compare differences among different cell and patient groups. Correlations were analyzed using linear regression. The $56 \mathrm{BC}$ patients were divided into high $(n=26)$ and low $(n=30)$ PLAC2 level groups (Youden's index). Survival curves were plotted using $\mathrm{K}-\mathrm{M}$ method and compared by logrank test. Chi-squared test was performed to analyze the correlations between the expression levels of PLAC2 and patients' clinical data. $P<0.05$ was statistically significant.

\section{Results}

\section{PLAC2 were significantly downregulated in BC}

The expression of PLAC2 in two types of tissue of $\mathrm{BC}$ patients $(n=56)$ were detected by RT-qPCR and the expression data were compared by paired $t$ test. The data revealed that the expression levels of PLAC2 were significantly lower in $\mathrm{BC}$ tissues in comparison to that in non-cancer tissues (Fig. 1a $p<0.05$ ). The expression levels of PLAC2 were slightly lower in high grade group than that in low grade group, but the difference was not significant (Fig. 1b, $p<0.05$ ). Chi-squared test showed that the expression levels of PLAC2 were not significantly correlated with patients' age, gender, multifocal tumors, CIS, cancer stages and tumor grades (Table 1).

\section{PLAC2 was not affect by clinical stages and low} expression levels of PLAC2 predicted lower survival rate The 56 patients were staged according to the AJCC criteria, and 12, 15, 15 and 14 cases were classified into stage I-IV, respectively. The expression levels of PLAC2 in $\mathrm{BC}$ were compared among different clinical stages using one-way ANOVA and Tukey test. No significant differences were observed among different clinical stages (Fig. 2a). In addition, survival curves showed that patients with low expression levels of PLAC2 had significantly worse overall survival rate (Fig. 2b). It is worth noting that the 56 patients included 26 cases with high grade and 30 cases with low grade. The expression levels of PLAC2 were slightly lower in high grade group in comparison to that in the low-grade group, but the difference was not significant ( $p<0.05$, data not shown).

\section{PLAC2 was positively correlated with miR-663 and inversely correlated with TGF- $\beta 1$ in BC tissues}

The expression of TGF- $\beta 1$ and miR-663 in BC tissues were also detected by RT-qPCR experiments. Correlations were analyzed by linear regression. It was observed that the expression of PLAC2 was positively correlated with the expression of miR-663 (Fig. 3a) and inversely correlated with TGF- $\beta 1$ (Fig. $3 \mathrm{~b}$ ) across BC tissues.

\section{A novel PLAC2/miR-663/TGF- $\beta 1$ pathway is involved in the regulation of $B C$ cell migration and invasion}

After transfections, the expression levels of PLAC2, miR-663 and TGF- $\beta 1$ were significantly altered at $24 \mathrm{~h}$ after transfections (Fig. 4a, $p<0.05$ ), indicating the successful transfections. In was observed that overexpression of PLAC2 resulted in upregulation of miR-663, while overexpression of miR-663 showed no significantly changed expression levels of PLAC2 (Fig. 4b, $p<0.05$ ).
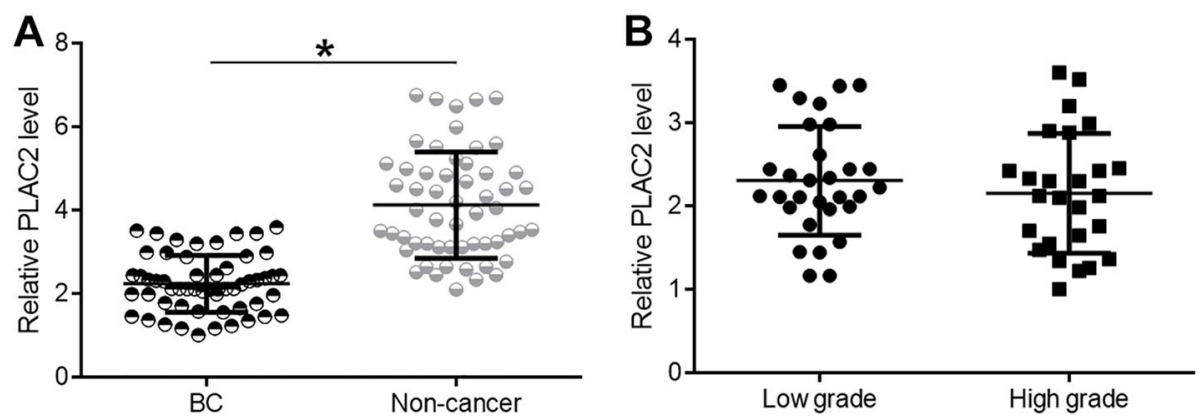

Fig. 1 PLAC2 were significantly downregulated in BC. PLAC2 detected by RT-qPCR and analyzed by paired test showed that expression levels of PLAC2 were significantly lower in BC tissues compared to that in non-cancer tissues (a). Expression levels of PLAC2 were slightly lower in high grade group than in low grade group, but the difference was not significant $(\mathbf{b}) .\left({ }^{*}, p<0.05\right)$ 
Table 1 Correlations between the expression levels of PLAC2 and patients' clinical data.

\begin{tabular}{|c|c|c|c|c|c|c|}
\hline Variables & Groups & Cases & High $(n=26)$ & Low $(n=30)$ & $x^{2}$ & $p$ value \\
\hline \multirow[t]{2}{*}{$\overline{\text { Age }}$} & $>65$ (years) & 34 & 16 & 18 & 0.01 & 0.91 \\
\hline & $<=65$ (years) & 22 & 10 & 12 & & \\
\hline \multirow[t]{2}{*}{ Gender } & Male & 40 & 19 & 21 & 0.06 & 0.80 \\
\hline & Female & 16 & 7 & 9 & & \\
\hline \multirow[t]{2}{*}{ Multifocal tumors } & Yes & 24 & 10 & 14 & 0.38 & 0.64 \\
\hline & No & 32 & 16 & 16 & & \\
\hline \multirow[t]{2}{*}{$\mathrm{CIS}$} & Yes & 12 & 5 & 7 & 0.14 & 0.71 \\
\hline & No & 44 & 21 & 23 & & \\
\hline \multirow[t]{4}{*}{ Tumor stage } & । & 12 & 5 & 7 & 0.47 & 0.93 \\
\hline & $\|$ & 15 & 7 & 8 & & \\
\hline & III & 15 & 8 & 7 & & \\
\hline & IV & 14 & 6 & 8 & & \\
\hline \multirow[t]{2}{*}{ Tumor grade } & High & 26 & 12 & 14 & 0.01 & 0.97 \\
\hline & Low & 30 & 14 & 16 & & \\
\hline
\end{tabular}

In addition, overexpression of PLAC2 and miR-663 resulted in the downregulation of TGF- $\beta 1$, while miR-663 inhibitor attenuated the effects of overexpression of PLAC2 (Fig. 4c, $p<0.05$ ). Moreover, overexpression of TGF- $\beta 1$ did not significantly affect the expression of PLAC2 and miR-663 (Fig. 4d). Therefore, a novel PLAC2/miR-663/TGF- $\beta 1$ pathway was characterized. It is worth noting that the targeting of TGF- $\beta 1$ by miR-663 has been well established [12]. Transwell migration and invasion assays were performed to investigate the involvement of the PLAC2/miR-663/TGF- $\beta 1$ pathway in regulating $\mathrm{BC}$ cell behaviors. It showed that overexpression of PLAC2 and miR-663 resulted in reduced rates of $\mathrm{BC}$ cell migration (Fig. 5a) and invasion (Fig. 5b), while overexpression of TGF- $\beta 1$ resulted in increased rates $(p<0.05)$. In addition, miR-663 inhibitor reduced the effects of overexpressing PLAC2 $(p<0.05)$. It is worth noting that our preliminary CCK- 8 assay resulted showed that PLAC2 had no significant effects on cell proliferation, apoptosis and stemness (data not shown).

\section{Discussions}

The functions of PLAC2 in BC and its clinical potentials for $\mathrm{BC}$ have been investigated in this study. We found that PLAC2 was downregulated in $\mathrm{BC}$ and played a tumor suppressive role by downregulating TGF- $\beta 1$ through the upregulation of miR-663, which can directly target TGF- $\beta 1$ in glioblastoma [12].

The TGF- $\beta$ signaling is a well-studied pathway in cancer biology [13]. TGF- $\beta$ inhibits cancer cell proliferation and function as a tumor suppressor in most types of cancer at initiation stages [14], while it also promotes tumor metastasis at late stages [14]. Our study didn't test the effects of overexpressing TGF- $\beta 1$ on BC cell migration and invasion because it has been well established that TGF- $\beta 1$ promotes the $\mathrm{BC}$ cell migration and inva-
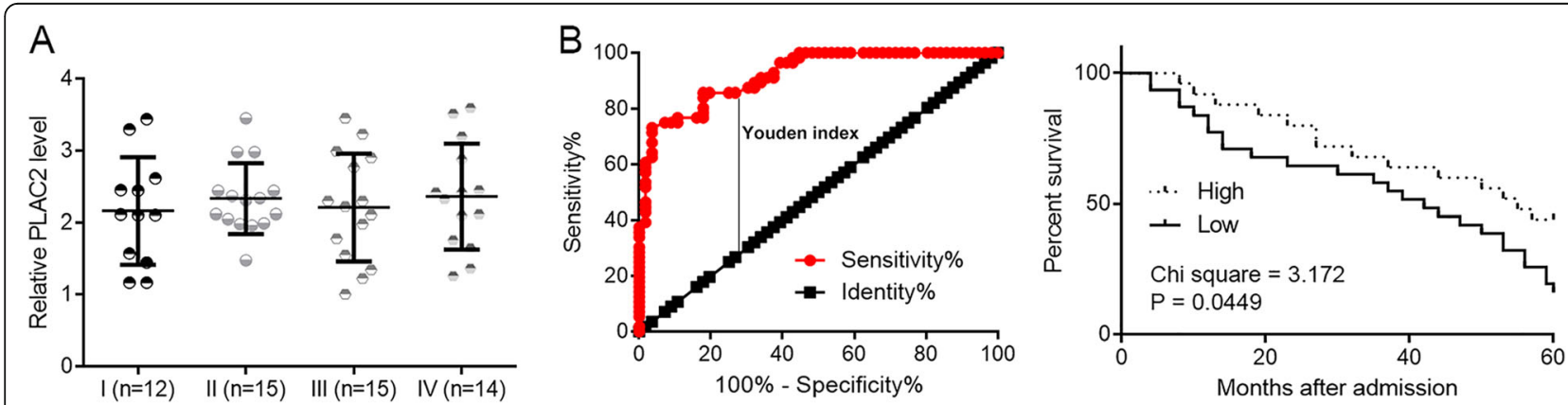

Fig. 2 PLAC2 was not affect by clinical stages and low PLAC2 levels predicted low survival rate. One-way ANOVA and Tukey test analysis showed no significant differences in expression levels of PLAC2 in BC tissues among different clinical stages (a). Survival curve analysis showed that patients with low levels of PLAC2 had significantly worse overall survival rate (b) 

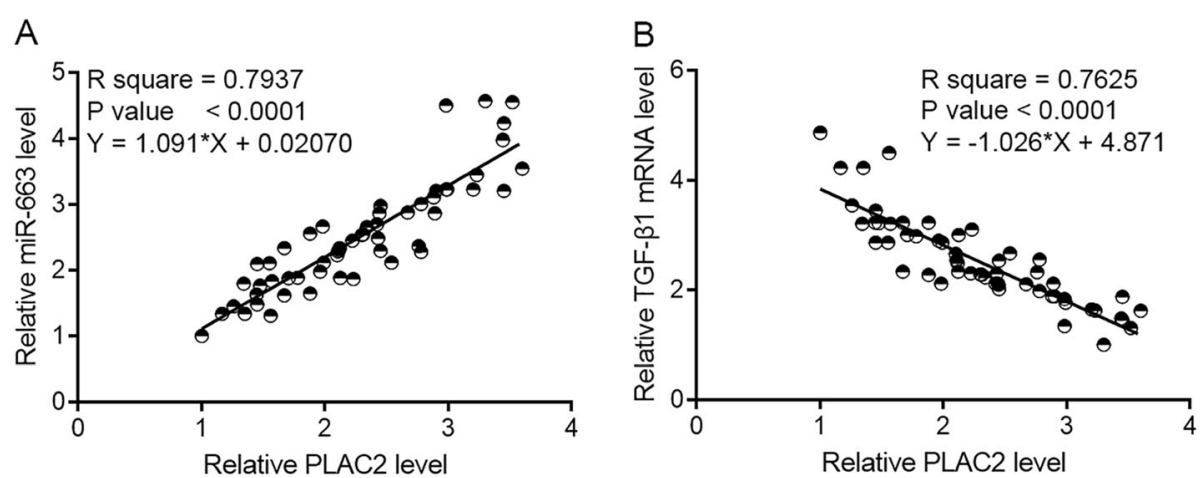

Fig. 3 PLAC2 was positively correlated with miR-663 and inversely correlated with TGF- $\beta 1$ in BC tissues. Linear regression showed that PLAC2 was positively correlated with miR-663 (a) and inversely correlated with TGF- $\beta 1$ (b) in BC tissues
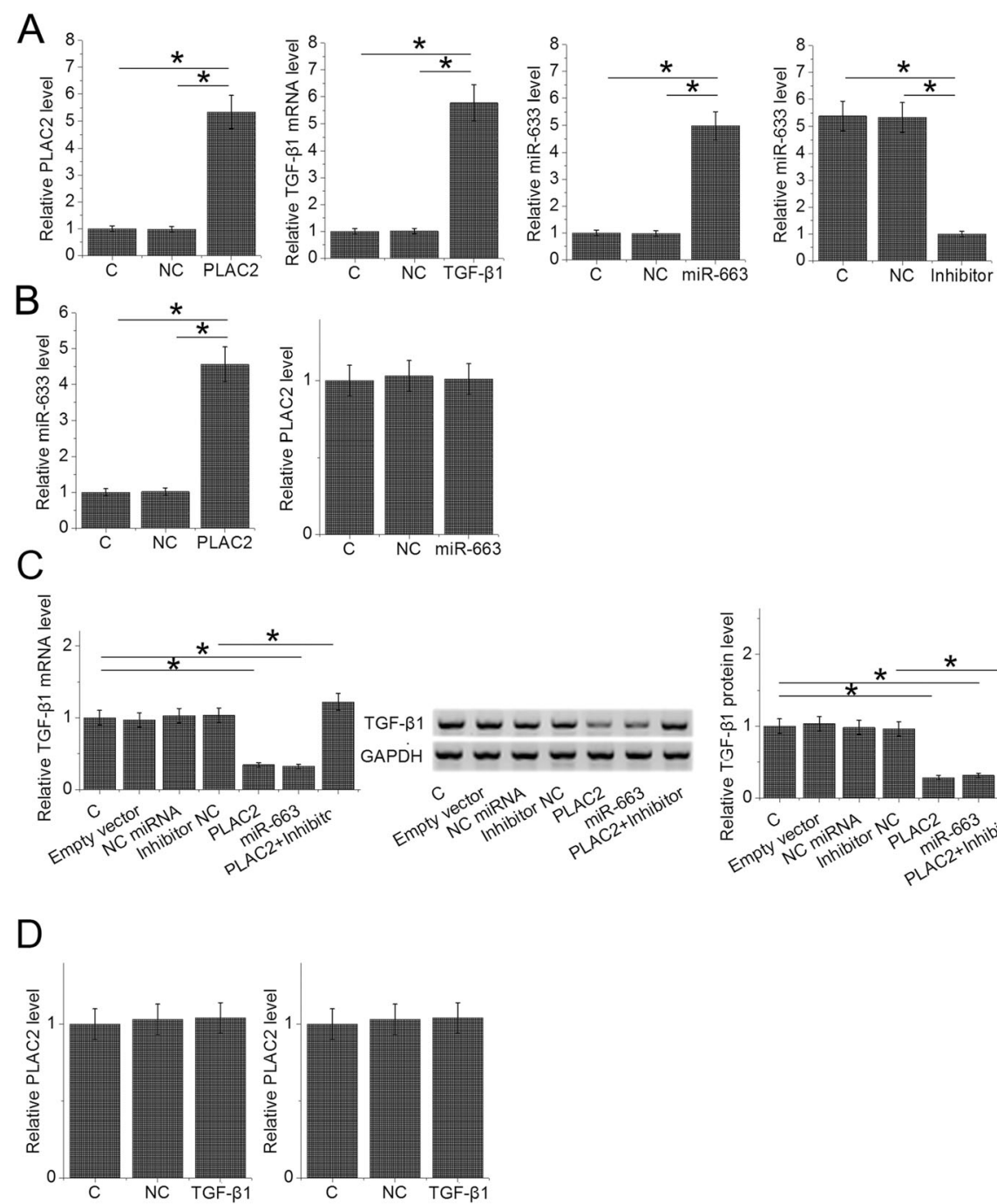

Fig. 4 A novel PLAC2/miR-663/TGF- $\beta 1$ pathway was characterized. RT-GPCR results showed the altered expression of PLAC2, miR-663 and TGF- $\beta 1$ at $24 \mathrm{~h}$ after transfections (a). Overexpression of PLAC2 resulted in upregulation of miR-663, while overexpression of miR-663 resulted in no significantly changed expression levels of PLAC2 (b). In addition, overexpression of PLAC2 and miR-663 resulted in the downregulation of TGF- $\beta 1$, while miR-663 inhibitor attenuated the effects of PLAC2 overexpression (c). Moreover, overexpression of TGF- $\beta 1$ did not significantly affect the expression of PLAC2 and miR-663 (d) $(*, p<0.05)$ 

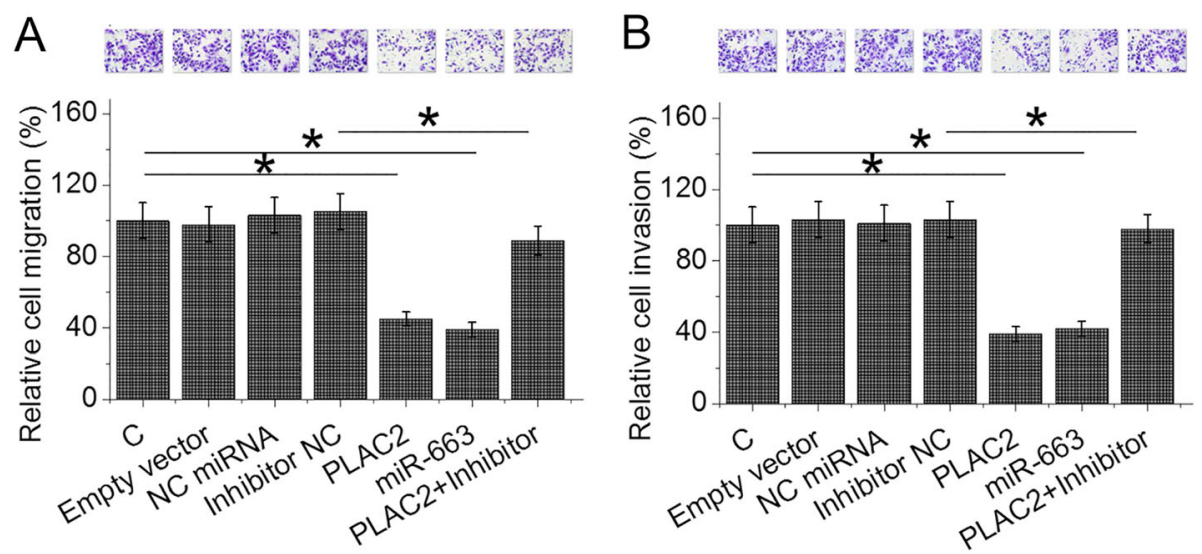

Fig. 5 PLAC2/miR-663/TGF- $\beta 1$ pathway is involved in the regulation of BC cell migration and invasion. Overexpression of PLAC2 and miR-663 resulted in reduced rates of BC cell migration (a) and invasion (b), while overexpression of TGF- $\beta 1$ resulted in the increased rates. In addition, miR-663 inhibitor reduced the effects of PLAC2 overexpression $\left({ }^{*}, p<0.05\right)$

sion through the interactions with multiple downstream pathways [15]. However, the TGF- $\beta$ signaling can also be inhibited by certain factors, such as miRNAs. A recent study reported that miR-663 can target TGF- $\beta 1$ to inhibit the behaviors of glioblastoma cells [12]. Our study observed the downregulation of TGF- $\beta 1$ in BC cell after the overexpression of miR-663. Therefore, miR-663 may also target TGF- $\beta 1$ in BC cells. These data suggest that, although $\mathrm{BC}$ and glioblastoma are two types of cancer that affect different organs, they may share similar molecular pathogenesis $[16,17]$.

Cancer prognosis is always important because it not only predicts the survival of patients within a time period but also helps the development of individualized treatment. PLAC2 is found to be a tumor suppressor in glioma [11]. The expression data of PLAC2 are not available in TCGA and CCLE database and we investigated its expression and functionality in this study. We found that PLAC2 is also a tumor suppressor in BC. Different from the roles of PLAC2 as a cell cycle inhibitor in glioma, PLAC2 functions as a migration and invasion inhibitor in BC. Therefore, the same lncRNA may play different roles in different types of cancer, which highlights the complicated molecular pathogenesis of cancers. BC patients with low expression levels of PLAC2 showed low 5-year survival rate, indicating its prognostic value for BC. Interestingly, PLAC2 was found to be an upstream activator of miR-663 in $\mathrm{BC}$ cells, and the upregulation of miR-663 is accompanied by the downregulation of TGF- $\beta 1$. Therefore, a novel PLAC2/miR-663/TGF- $\beta 1$ pathway was characterized as a pathway involved in the regulation of $\mathrm{BC}$ cell behaviors. LncRNAs can inhibit miRNAs by serving as their endogenous sponge [18-20]. However, we observed the upregulation of miR-663 by PLAC2. We speculate certain mediators may exist between PLAC2 and miR-663. Our future studies will test this possibility.
Interestingly, the expression of PLAC2 was not significantly affected by clinical stages, while PLAC2 showed significant effects on cancer cell invasion and migration. It is well-known that different genetic factors participate in different stages of cancer [21]. We speculate that certain factors can inhibit the roles of PLAC2 in cell invasion and migration at early cancer stages, while it does not inhibit at advanced stages and in cancer cell lines. It is worth noting that we did not perform wound healing assay to measure the migration of cells under different conditions. Our future studies will perform wound healing assay to further confirm our conclusions. The present study only included one cell line. Our future studies will include more cell lines to further confirm our conclusions. The overexpression of TGF- $\beta 1$ is only confirmed at mRNA level, which is a limitation. Our future study will solve this problem.

\section{Conclusions}

In conclusion, PLAC2 was downregulated in $\mathrm{BC}$ and PLAC2 may upregulate miR-663 to downregulate TGF$\beta 1$, thereby inhibiting $\mathrm{BC}$.

\section{Supplementary information}

Supplementary information accompanies this paper at https://doi.org/10. 1186/s12894-020-00663-w.

\section{Additional file 1.}

Abbreviations

BC: Bladder cancer; IncRNAs: Long (> $200 \mathrm{nt}$ ) non-coding RNAs

\section{Acknowledgements}

Not applicable.

Authors' contributions

$\mathrm{PA}, \mathrm{HH}, \mathrm{QZ}, \mathrm{YC}, \mathrm{JH}, \mathrm{QH}, \mathrm{HH}$ data collection and analysis, manuscript written and revision, ZZ, DZ study design, literature review, data collection and 
analysis, manuscript written and revision. All authors have read and approved the manuscript.

\section{Funding}

This work was supported by National Natural Science Foundation of China (Grant No. 81802559).

\section{Availability of data and materials}

The analyzed data sets generated during the study are available from the corresponding author on reasonable request.

\section{Ethics approval and consent to participate}

The present study was approved by the Ethics Committee The first affiliated hospital of Wannan Medical College. The research has been carried out in accordance with the World Medical Association Declaration of Helsinki. All patients provided written informed consent prior to their inclusion within the study.

\section{Consent for publication}

Not applicable.

\section{Competing interests}

The authors declare that they have no competing interests.

Received: 20 August 2019 Accepted: 26 June 2020

Published online: 10 July 2020

\section{References}

1. Siegel R, Naishadham D, Jemal A. Cancer statistics, 2013. CA Cancer J Clin. 2013;63(1):11-30

2. Ferlay J, Shin HR, Bray F, et al. Estimates of worldwide burden of cancer in 2008: GLOBOCAN 2008. Int J Cancer. 2010;127(12):2893-917.

3. Chang SS, Bochner BH, Chou R, et al. Treatment of non-metastatic muscleinvasive bladder cancer: AUA/ASCO/ASTRO/SUO guideline. J Urol. 2017; 198(3):552-9.

4. Kamat AM, Hahn NM, Efstathiou JA, et al. Bladder cancer. Lancet. 2016; 388(10061):2796-810.

5. Carneiro BA, Meeks JJ, Kuzel TM, et al. Emerging therapeutic targets in bladder cancer. Cancer Treat Rev. 2015;41(2):170-8.

6. Schmitt AM, Chang HY. Long noncoding RNAs in cancer pathways. Cancer Cell. 2016;29(4):452-63.

7. Peng WX, Koirala P, Mo YY. LncRNA-mediated regulation of cell signaling in cancer. Oncogene. 2017;36(41):5661-7.

8. Fan $\mathrm{YH}, \mathrm{Ji} \mathrm{C}, \mathrm{Xu} \mathrm{B}$, et al. Long noncoding RNA activated by TGF- $\beta$ in human cancers: a meta-analysis. Clin Chim Acta. 2017;468:10-6.

9. Wu W, Chen F, Cui X, et al. LncRNA NKILA suppresses TGF- $\beta$-induced epithelial-mesenchymal transition by blocking NF-KB signaling in breast cancer. Int J Cancer. 2018;143(9):2213-24.

10. Boon RA, Jaé N, Holdt L, et al. Long noncoding RNAs: from clinical genetics to therapeutic targets? J Am Coll Cardiol. 2016;67(10):1214-26.

11. Hu YW, Kang CM, Zhao JJ, et al. Lnc RNA PLAC 2 down-regulates RPL 36 expression and blocks cell cycle progression in glioma through a mechanism involving STAT 1. J Cell Mol Med. 2018;22(1):497-510

12. Li Q, Cheng Q, Chen Z, et al. MicroRNA-663 inhibits the proliferation, migration and invasion of glioblastoma cells via targeting TGF- $\beta 1$. Oncol Rep. 2016;35(2):1125-34

13. Syed V. TGF- $\beta$ signaling in Cancer. J Cell Biochem. 2016;117(6):1279-87.

14. Seoane J, Gomis RR. TGF- $\beta$ family signaling in tumor suppression and cancer progression. Cold Spring Harb Perspect Biol. 2017:9(12):a022277.

15. Gupta $\mathrm{S}$, Hau AM, Al-Ahmadie HA, et al. Transforming growth factor- $\beta$ is an upstream regulator of mammalian target of rapamycin complex $2-$ dependent bladder cancer cell migration and invasion. Am J Pathol. 2016; 186(5):1351-60.

16. Ponder BAJ. Cancer genetics. Nature. 2001;411(6835):336-41.

17. You JS, Jones PA. Cancer genetics and epigenetics: two sides of the same coin? Cancer Cell. 2012;22(1):9-20.

18. Liz J, Esteller M. IncRNAs and microRNAs with a role in cancer development. Biochim Biophys Acta Gene Regul Mech. 2016;1859(1):169-76.

19. Paraskevopoulou MD, Hatzigeorgiou AG. Analyzing miRNA-IncRNA interactions. Long Non-Coding RNAs. New York: Humana Press; 2016. p. 271-86.
20. Thomson DW, Dinger ME. Endogenous microRNA sponges: evidence and controversy. Nat Rev Genet. 2016;17(5):272-83.

21. Cheng L, Zhang S, MacLennan GT, et al. Bladder cancer: translating molecular genetic insights into clinical practice. Hum Pathol. 2011;42(4): $455-81$.

\section{Publisher's Note}

Springer Nature remains neutral with regard to jurisdictional claims in published maps and institutional affiliations.
Ready to submit your research? Choose BMC and benefit from:

- fast, convenient online submission

- thorough peer review by experienced researchers in your field

- rapid publication on acceptance

- support for research data, including large and complex data types

- gold Open Access which fosters wider collaboration and increased citations

- maximum visibility for your research: over $100 \mathrm{M}$ website views per year

At $\mathrm{BMC}$, research is always in progress.

Learn more biomedcentral.com/submissions 